\title{
Effect of Dietary Supplementation of Full-Fat Canola Seeds on Productive Performance, Blood Metabolites and Antioxidant Status of Laying Japanese Quails
}

Original Article

-Author(s)

Ibrahim NS' (iD https://orcid.org/0000-0003-4907-2905 Sabic EM' (DD https://orcid.org/0000-0003-4945-9982 Abu-Taleb AM' (iD https://orcid.org/0000-0002-3747-0263 Abdel-Moneim AE' (D) https://orcid.org/0000-0002-0199-6298

Biological Applic. Dep, Nuclear Res. Center, Atomic Energy Authority, P.O. Box 13759, Egypt.

\section{-Mail Address}

Corresponding author e-mail address Nashat Saeid Ibrahim

Biological Applic. Dep., Nuclear Res. Center, Atomic Energy Authority, Inshas, Egypt, P.O, Box 13759

Phone: (0202) 01119992240

Email: nashaat1977@yahoo.com

\section{- Keywords}

Full-fat canola seed, performance, blood metabolities, antioxidant, laying quail.

\section{ABSTRACT}

The present study was carried out to evaluate the effects of dietary supplementation of different levels of full-fat canola seeds (FFCS) on productive performance, blood metabolites and antioxidant status of laying Japanese quails. A total of 360, 8-week-old quails were divided into a completely randomize design with 4 dietary experimental groups and three pens each, each pen containing 30hens. The experimental groups were fed iso-caloric and iso-nitrogenous diets supplemented with FFCS at levels 0, 50, 100 and $150 \mathrm{~g} / \mathrm{kg}$ diet. The experiment lasted 16 weeks. All supplemented groups showed significant effects in the final body weight $(\mathrm{g})$, hen feed consumption ( $\mathrm{g} / \mathrm{hen} /$ day), egg mass ( $\mathrm{g}$ egg/hen/day) and hen-day egg production (\%). However, egg weight (g) at 8-12 weeks of age reduced significantly. Moreover, feed conversion ratio (g feed/g egg), did not alter among groups. Egg quality criteria were not affected by FFCS supplementationexcept for the egg shape index which decreased significantly at 10 and 15\% FFCS groups. Serum total protein, albumen, uric acid, creatinine, hepatic enzyme activities, triiodothyronine, total cholesterol and HDL-cholesterolconcentrations were not altered. However, serum triglycerides and LDL-cholesterol showed significant reduction in all treated groups. Furthermore, serum glutathione peroxidase level was greatly influencedin supplemented groups, while malondialdehyde level reduced significantly. In conclusion, FFCS inclusion in Laying Japanese quail diets up to 15\% enhanced the laying performance, blood lipids profile and anti-oxidative status. Thus, it can be regarded as alternative sources of energy and protein in poultry rations.

\section{INTRODUCTION}

Nutrition is one of the major factors impacting the expansion of animal and poultry production, basically due to the constant elevation in prices of conventional dietary ingredients (yellow corn and soybean), which leads poultry nutritionists to search for appropriate, cheap and high-quality alternative feedstuffs (Farahat et al., 2013; Abd ElMoneim \& Sabic, 2019; Abd El-Moneim et al., 2019). Canola seeds (CS), considered one of the locally and available crops in Egypt, have been tested as a good alternative to partly substitute yellow corn and soybean in poultry diets (Najib \& Al-Khateeb, 2004) without causing loss in productive performance. However, its usage is still restricted due to the low available energy and the presence of detrimental components, just as (glucosinolates, erucic acid, phenols, sinapine, phytic acid, tannins and fiber), which influence its nutritional value and reduced the digestibility of proteins and bioavailability of minerals in the intestine (Mailer et al., 2008; Khajali \& Slominski, 2012; Jasinski et al., 2018). For these reasons, Egyptian scientists in crop plant breeders, have successfully employed mutagenesis techniques, using gamma 
radiation in CS and could establish a promising mutant line of canola seeds (MCS), which showed significant impact on seed yields, $40-45 \%$ oil in seeds and at least $28 \%$ protein, $3.5 \%$ fat and $0.35 \%$ phosphorus than their parents (Amer et al., 2017; Farrag, 2019). The fatty acid composition of MCS showed also a high level of unsaturated fatty acids (61\%), low level of saturated fatty acids (7\%), oleic acid (51.26\%), linoleic acid (17.32\%) and linoleic acid (9.38\%). In addition, they markedly minimized its anti-nutritional substances, including, glucosinolate and erucic acid to a negligible degree (Anwar et al., 2015; Amer et al., 2017). To our knowledge, no studies were conducted concerning this innovation of MCS and its use as a local dietary alternative ingredient in laying quail diets. Therefore, this study aims to evaluate the effects of incorporating increasing levels of FFCS as an alternative feed supplement on productive performance, blood metabolites and antioxidant status of laying Japanese quails.

\section{MATERIALS AND METHODS}

\section{Birds' ethics and husbandry}

The feeding experiment was conducted with 8 week old laying Japanese quail birds which were maintained at the Poultry experimental farm of the biological application department, Nuclear Research Center, Egypt. All procedures were carried out according to the guidelines of the Institutional Animal Care and Use Committee for animal research, which is a member of the Egyptian Network of Research Ethics Committee. The scientific and ethics committee of the Biological Application Department, Nuclear Research Center, Egypt approved all procedures used in this experiment (protocol number 186; date of approval: 14-7-2019).

\section{Chemical analysis and Anti-nutritional compounds of CS}

Proximate analysis of moisture, protein, fat, crude fiber, total carbohydrates and ash content were determined according to A.O.A.C (2010). Phytic acid content was determined using chromogenic reagent according to the method described by (Mohamed et al.,1986). The glucosinolate content of the samples was determined according to (Gardrat \& Prevot, 1987). In-vitro protein digestibility (IVPD) was estimated according to the method of (Akesonand Stahman, 1984) using the following the equation:

$$
\text { IVPD }=\frac{\text { Nitrogen in supernatant }}{\text { Total nitrogen in the samples }} \times 100
$$

The chemical analysis, anti-nutritional compounds and in-vitro protein digestibility of CS were shown in Table 1.

Table 1 - Chemical composition of canola seeds on dry weight basis.

\begin{tabular}{lcc}
\hline Items & $\begin{array}{c}\text { Traditional } \\
\text { canola seeds }\end{array}$ & $\begin{array}{c}\text { Mutant } \\
\text { canola seeds }\end{array}$ \\
\hline Moisture \% & 5.8 & 4.82 \\
Crude protein\% & 22.3 & 23.2 \\
Crude oil\% & 47.58 & 48.9 \\
Crude fiber\% & 11.0 & 9.8 \\
Ash\% & 2.95 & 2.83 \\
Total carbohydrates \% & 10.10 & 10.45 \\
\hline Antinutrational factors & & \\
\hline Phytic acid g/kg & 26.2 & 12.2 \\
Total glycosinolate $\mu \mathrm{mol} / \mathrm{g}$ & 22.7 & 7.4 \\
In-vitro protein digestibility $\mathrm{g} / 100 \mathrm{~g}$ & 57 & 62.1 \\
\hline
\end{tabular}

\section{Birds and Management}

A total of 360, 8-week-old Japanese quail hens with average $242.1 \pm 1.54 \mathrm{~g}$, initial body weight per female were divided into a completely randomized design with 4 dietary experimental groups and three pens each, each pen containing 30 hens. The experimental birds equal in body weight were housed in steel wire battery cages of $(100 \times 60 \times 50 \mathrm{~cm}$; length $\times$ width $x$ height) in size, in an experimental house under the same management, hygienic and environmental conditions; a 16- hour's lighting schedule and ambient temperature ranged from $20-25{ }^{\circ} \mathrm{C}$ during eight weeks experiment period. Cages were equipped with a stainless-steel nipple drinker.

\section{Experimental diets and Canola seed source}

The experimental diets were conducted on mutant line of full fat Canola seed (Brassica napusL.), which had been genetically improved and produced in previous studies conducted by (Amer et al., 2017) in plant breeding techniques process, through exposing the traditional canola seed to gamma radiation applications then growing the irradiated seed for several generations in the experimental fields of the plant research department, Nuclear Research Center, Egypt. The full-fat canola seed was dried and finely grinded using a grinder before supplementations to laying Japanese quail diets. For 16 weeks, the experimental groups as shown in Table 2, fed iso-caloric and isonitrogenous diets supplemented with FFCS at different levels of $0,50,100$ and $150 \mathrm{~g} / \mathrm{kg}$ diet, respectively. The first group (CO) received a basal diet based on yellow corn-soybean meal with no FFCS and served as control. The other treatments ( $C 5, C 10$ and $C 15)$ were fed the basal diet supplemented with FFCS at different 
levels 50, 100 and $150 \mathrm{~g} / \mathrm{kg}$ diet, respectively. Diets were formulated according to NRC (1994) to cover the nutrient requirements of laying quails. Mash diets and drinking water were available ad libitum for each cage during the whole study. The diets composition and the calculated analysis are presented in Table 2.

Table 2 - Composition and calculated analysis of experimental diets of laying Japanese quail.

\begin{tabular}{|c|c|c|c|c|}
\hline \multirow{2}{*}{ Item } & \multicolumn{4}{|c|}{ Canola seeds concentrations } \\
\hline & $\mathrm{CS}(0 \%)$ & CS (5\%) & CS $(10 \%)$ & CS (15\%) \\
\hline \multicolumn{5}{|l|}{ Ingredients, \% } \\
\hline yellow maize & 53.88 & 52.67 & 51.72 & 49.24 \\
\hline soybean meal (44\%) & 34.50 & 32.48 & 30.43 & 28.70 \\
\hline dicalcium phosphate & 1.20 & 0.90 & 0.60 & 0.30 \\
\hline limestone & 5.70 & 5.85 & 5.95 & 6.10 \\
\hline sodium chloride & 0.30 & 0.30 & 0.30 & 0.30 \\
\hline vitamin-mineralpremix ${ }^{1}$ & 0.30 & 0.30 & 0.30 & 0.30 \\
\hline dl-methionine & 0.12 & 0.10 & 0.10 & 0.06 \\
\hline soybean oil & 4.00 & 2.40 & 0.6 & 0.00 \\
\hline full fat canola seeds & 0.00 & 5.00 & 10.0 & 15.0 \\
\hline \multicolumn{5}{|l|}{ Calculated values², \% } \\
\hline crude protein & 20.04 & 20.02 & 20.04 & 20.02 \\
\hline metabolizable energy (ME) MJ/kg & 12.20 & 12.22 & 12.20 & 12.41 \\
\hline crude fibre & 3.60 & 4.03 & 4.47 & 4.89 \\
\hline lysine & 1.14 & 1.18 & 1.21 & 1.25 \\
\hline methionine & 0.45 & 0.45 & 0.47 & 0.49 \\
\hline methionine + cysteine & 0.80 & 0.78 & 0.75 & 0.71 \\
\hline calcium & 2.51 & 2.52 & 2.51 & 2.52 \\
\hline available phosphorus & 0.36 & 0.36 & 0.36 & 0.36 \\
\hline
\end{tabular}

${ }^{\prime}$ vitamin-mineral premix provided per kg diet: IU: vit. A 12,000 , vit. D, 5,000; g: vit. E 16.7 , vit. K 0.67 , vit. $B, 0.67$, vit. $B_{2} 2$, vit. B 67 , vit. $B_{12} 0.004$, nicotinic acid 16.7 , pantothenic acid 6.67, biotin 0.07 , folic acid 1.67, choline chloride 400, Zn 23.3, Mn 10, Fe 25, Cu 1.67, I 0.25, Se 0.033, Mg 133.4; ${ }^{2}$ calculated according to National Research Council (NRC, 1994).

\section{Productive performance and egg parameters measured}

The individual live body weight of quail hen per replicate was recorded at the beginning and at the end of the experiment however feed consumption (FC) $\mathrm{g}$ feed/bird/day was registered per week. Feed conversion ratio (FCR) was estimated as: $\mathrm{g}$ feed /g egg. Egg number (EN) and egg weight (EW) were monitored daily to calculate \%Hen-day egg production and the egg mass (EM) g/hen/day as: $\mathrm{EM}=\mathrm{EN} \times \mathrm{EW}$.

\section{Egg quality criteria}

Egg and eggshell quality examinations (eggshell thickness, shell, yolk and albumen weights (\%), yolk index, yolk: albumen ratio, egg shape index and Haugh Unite (HU) score were conducted according to (William, 1992) by using an average of 10 eggs laid between 12:00 and 15:00 from each treatment replicate which were randomly collected at the ends of 8,12 , and 16 weeks of age. To measure external and internal egg quality criteria, after the eggs were weighed and measured in their length and width, egg shape index was calculated as the ratio of egg width to length, the eggs were carefully opened on a glass plate, then both yolk and albumen were separated and weighed, while eggshells were cleaned, dried at room temperature and weighed. Yolk, albumen and shell weights were expressed as a percentage of egg weight. Mean eggshell thickness (with shell membrane) at three areas of the egg (air cell, equator and sharp end) was determined using a $0.01-\mathrm{mm}$ micrometer. Yolk diameter was estimated by a vernier caliper to the nearest $0.05 \mathrm{~mm}$, however yolk height was measured to the nearest $0.01 \mathrm{~mm}$ by means of tripod micrometer reading. The yolk index was calculated by dividing the yolk height on yolk diameter. HU score was computed according the following equation:

$\mathrm{HU}(\%)=100 \times \log \left(\mathrm{T}+7.57-1.7 \times \mathrm{M}^{0.37}\right)$ where: $\mathrm{T}$ and $\mathrm{M}$ refer to albumen height and egg weight $\mathrm{g}$, respectively.

\section{Blood sampling and biochemical analysis}

At the termination of the experiment, 9 quail hens from each group (3 hens / pen), were randomly selected, slaughtered and blood samples were collected in a tube without anticoagulant for separate serum; then the samples were immediately centrifuged at $4500 \mathrm{rpm}$ for $15 \mathrm{~min}$ and the obtained sera was frozen at $-20^{\circ} \mathrm{C}$ until further analysis. Serum total protein, albumin, total cholesterol (TC), triglycerides (TG), low- 
density lipoprotein (LDL) and high-density lipoprotein (HDL) cholesterol, uric acid, creatinine concentrations, alkaline phosphatase (ALP) aspartate aminotransferase (AST), alanine aminotransferase (ALT) activities were analyzed using spectrophotometer (Spectronic 1201, Milton Roy, Ivyland, PA, USA) using commercial kits (Spinreact Co., Girona, Spain). Glutathione (GSH) and malondialdehyde (MDA) contents, and glutathione peroxidase (GPx) activity in the serum were analyzed using commercial kits (Cell Bio-labs Inc., San Diego, (A, USA). Serum concentration of triiodothyronine (T3) was measured in all blood samples using radioimmunoassay (RIA) kits.

\section{Statistical analysis}

The experimental results were analyzed with the general linear model and analysis of variance procedure using the statistical software SPSS (ver. 18.0; IBM Corp., Armonk, NY, USA). Tukey's procedure for multiple comparison tests was used to identify the statistical significant effects at a significance level of $p<0.05$. Linear and quadratic effects of dietary FFCS supplement level were studied using polynomial contrasts.

\section{RESULTS AND DISCUSSIONS}

\section{Laying quail performance}

Laying performance of laying quails as influenced by increasing dietary supplementation of FFCS is presented in Table 3. The obtained results show that, at the end of the experimental period ( $8 \mathrm{wks}$ ) the final body weight (g), hen feed consumption ( $\mathrm{g} /$ hen/day), overall egg mass ( $g$ egg/hen/day) and henday egg production (\%) of supplemented groups recorded significant effects in groups supplemented with increasing FFCS up to $15 \%$ in the diet compared to the control group. On the other hand, increasing the inclusion levels of FFCS from 10 to $15 \%$ in laying quail diets reduced significantly egg weight $(\mathrm{g})$ at 8-12 weeks of age, except, at 12-16 weeks of age in the group supplemented with 15\% FFCS. Moreover, feed conversion ratio, $\mathrm{g}$ feed/g egg was not significantly altered among groups.

The enhancing effects of FFCS on aforementioned laying performance may be due tothe genetic improvement in traditional CS, which was developed by scientists in crop plant breeders (Amer et al.,

Table 3 - Effect of dietary supplementation of canola seeds on productive performance of laying Japanese quail birds.

\begin{tabular}{|c|c|c|c|c|c|c|c|}
\hline \multirow{2}{*}{ Indices } & \multicolumn{4}{|c|}{ Dietary treatments ${ }^{1}$} & \multirow{2}{*}{$\mathrm{SEM}^{2}$} & \multicolumn{2}{|c|}{$p$-value } \\
\hline & CS $(0 \%)$ & CS (5\%) & CS (10\%) & CS(15\%) & & Linear & Quadratic \\
\hline \multicolumn{8}{|l|}{ Body weight, $g$} \\
\hline initial & 243.28 & 240.85 & 242.75 & 242.15 & 1.541 & 0.981 & 0.697 \\
\hline final & $266.26^{b}$ & $286.96^{a}$ & $285.24^{\mathrm{a}}$ & $296.25^{a}$ & 3.517 & 0.002 & 0.457 \\
\hline \multicolumn{8}{|c|}{ Feed consumption, g/bird/day } \\
\hline weeks 8-12 & $21.49^{b}$ & $24.94^{\mathrm{a}}$ & $26.27^{\mathrm{a}}$ & $25.13^{a}$ & 0.630 & 0.007 & 0.017 \\
\hline weeks $12-16$ & $24.85^{c}$ & $27.35^{b}$ & $28.81^{\mathrm{ab}}$ & $30.17^{a}$ & 0.637 & $<0.001$ & 0.324 \\
\hline overall & $23.17^{\mathrm{b}}$ & $26.14^{\mathrm{a}}$ & $27.54^{\mathrm{a}}$ & $27.64^{a}$ & 0.582 & $<0.001$ & 0.017 \\
\hline \multicolumn{8}{|c|}{ Feed conversion ratio, g feed/g egg } \\
\hline weeks 8-12 & 2.45 & 2.61 & 2.78 & 2.56 & 0.079 & 0.499 & 0.267 \\
\hline weeks $12-16$ & 2.60 & 2.56 & 2.48 & 2.43 & 0.036 & 0.076 & 0.960 \\
\hline overall & 2.53 & 2.59 & 2.61 & 2.49 & 0.045 & 0.869 & 0.400 \\
\hline \multicolumn{8}{|l|}{ Egg weight, g } \\
\hline weeks 8-12 & $13.16^{a}$ & $12.91^{\mathrm{ab}}$ & $12.83^{b}$ & $12.55^{c}$ & 0.075 & 0.001 & 0.863 \\
\hline weeks 12-16 & $13.33^{\mathrm{a}}$ & $13.13^{b}$ & $12.98^{b}$ & $13.45^{\mathrm{a}}$ & 0.061 & 0.514 & 0.001 \\
\hline overall & $13.25^{\mathrm{a}}$ & $13.02^{b}$ & $12.91^{b}$ & $13.00^{b}$ & 0.042 & 0.002 & 0.006 \\
\hline \multicolumn{8}{|c|}{ Hen-day egg production, $\%$} \\
\hline weeks 8-12 & $66.52^{b}$ & $73.81^{\text {a }}$ & $73.62^{a}$ & $77.86^{\mathrm{a}}$ & 1.121 & $<0.001$ & 0.378 \\
\hline weeks $12-16$ & $71.43^{c}$ & $80.95^{b}$ & $89.00^{\mathrm{a}}$ & $92.06^{a}$ & 1.640 & $<0.001$ & 0.013 \\
\hline overall & $68.98^{d}$ & $77.38^{c}$ & $81.31^{b}$ & $84.96^{a}$ & 1.282 & $<0.001$ & 0.065 \\
\hline \multicolumn{8}{|c|}{ Egg mass, g egg/hen/day } \\
\hline weeks 8-12 & 8.83 & 9.56 & 9.54 & 9.83 & 0.204 & 0.135 & 0.592 \\
\hline weeks 12-16 & $9.56^{c}$ & $10.70^{b}$ & $11.65^{\mathrm{ab}}$ & $12.46^{a}$ & 0.350 & $<0.001$ & 0.581 \\
\hline overall & $9.19^{b}$ & $10.13^{\mathrm{ab}}$ & $10.59^{a}$ & $11.11^{\mathrm{a}}$ & 0.248 & 0.002 & 0.509 \\
\hline
\end{tabular}

'treatment groups: CSO - corn-based diet, CS5 - $50 \mathrm{~g}$ canola seed $/ \mathrm{kg}$, CS10 - $100 \mathrm{~g}$ canola seed $/ \mathrm{kg}$, CS15 - $150 \mathrm{~g}$ canola seed $/ \mathrm{kg}$; 2 SEM - standard error of means; a-c- means with different superscripts are significantly different. 
2017; Farrag, 2019). This enhanced seed as shown in Table 1 of this study are characterized with low concentration of total glycosinolate $7.4 \mu \mathrm{mol} / \mathrm{g}$ seed, Phytic acid $12.2 \mathrm{~g} / \mathrm{kg}$ seed and high level of in-vitro protein digestibility $62.1 \mathrm{~g} / 100 \mathrm{~g}$ in comparison with the traditional CS. Although, Niemann et al. (2018) documented no deleterious effects in performance of broilers fed diet with $15.8 \mu \mathrm{mol}$ glucosinolate /g diet. As a result, this improvement in FFCS characterizations, allowed for high level incorporation of canola seeds up to $15 \%$ into laying quail diets without causing any negative effects on the laying performance. Furthermore, a possible explanation for improving laying quail performance in the present study may be the high nutritive value of FFCS with high quality and content of oil percent, $48.9 \%$ in CS, high level of essential minerals and a better quality of proteins $23.2 \%$ in terms of balanced essential amino acid composition and digestibility $62.1 \mathrm{~g} / 100 \mathrm{~g}$. Besides, CS contain high percentage of unsaturated fatty acids $93.44 \%$, mainly $61.69 \%$ oleic acid, $22.12 \%$ linoleic and $6.32 \%$ linolenic acid (Farrag, 2019), these essential fatty acids of canola oil are involved in its utilization mode, taste and suitable odor, lead to increasing hen feed consumption ( $\mathrm{g} /$ hen/day), which in turn correlate with the significant increase in hen-day egg production (\%), egg mass ( $\mathrm{g}$ egg/hen/day) and improving the final body weight of supplemented groups. Moreover, feeding birds on diets containing unsaturated fatty acids has improved their lipid metabolism and productive performance (Keum et al., 2018). In accordance with obtaining results, (Przybylski et al., 2013; Sharafi et al., 2015) reported $7 \%$ saturated acids, including palmitic and stearic acid, and high levels of unsaturated fatty acids $93 \%$, including $61 \%$ oleic acid, $11 \%$ linolenic acid, and $21 \%$ linoleic acid in CS, this unique composition may provide the laying quail with essential fatty acids, energy and bioactive materials during the bird's life production resulted in a positive impact on egg production and egg weight ( Sharafi et al., 2015; Ibrahim et al., 2018). The results are in line with the findings of Zanini et al. (2006) who reported a significant increase in body weight gain in broilers fed a diet containing canola seed oil. Najib \& Al-Khateeb (2004) also reported no negative impact in productive performance and egg quality traits in laying fed canola meal up to $10 \%$ in the diet. In addition, Naseem et al., 2006 showed better body weight gain and feed utilization efficiency in chickens fed diet containing $25 \%$ canola meal.

\section{Egg quality}

The data of egg quality evaluated in response to the dietary supplementation of FFCS are presented in Table 4. There were no significant effects in (albumen, yolk and shell) percentages, yolk index, yolk: albumen ratio, Shell thickness, $\mathrm{mm}$ and haugh unit score among treatments, except for egg shape index which decreased significantly at10 and 15\% FFCS.

The non-significant changes in aforementioned egg quality characters in all supplemented groups agree with previous findings ( Kucukersan et al., 2010; Agah et al., 2010; Ismail et al., 2013), which showed insignificant difference of egg quality traits in laying hens fed diet supplemented with canola oil over $10 \%$. A similar study by Najib \& Al-Khateeb (2004) reported no negative impact in egg quality criteria in laying hen fed canola meal up to $10 \%$ in the diet. Moreover, the significant decrease in egg shape index by raising the inclusion levels of FFCS in laying quail diets may be attributed to the significant elevation in hen-day egg production (\%) and egg weight of supplemented groups with FFCS. This finding agrees with lqbal et al. (2017) who reported a correlation between egg weight and the egg shape index.

Table 4 - Effect of dietary supplementation of canola seeds on egg quality of laying Japanese quails birds at the end of the experimental period.

\begin{tabular}{|c|c|c|c|c|c|c|c|}
\hline \multirow{2}{*}{ Indices } & \multicolumn{4}{|c|}{ Dietary treatments ${ }^{1}$} & \multirow{2}{*}{$\mathrm{SEM}^{2}$} & \multicolumn{2}{|c|}{$p$-value } \\
\hline & $\operatorname{CS}(0 \%)$ & CS (5\%) & CS $(10 \%)$ & CS $(15 \%)$ & & Linear & Quadratic \\
\hline Albumen, \% & 55.39 & 54.73 & 55.74 & 54.27 & 0.349 & 0.459 & 0.572 \\
\hline Yolk, \% & 30.02 & 30.50 & 30.52 & 30.98 & 0.257 & 0.225 & 0.986 \\
\hline Shell, \% & 14.59 & 14.78 & 13.74 & 14.75 & 0.258 & 0.818 & 0.435 \\
\hline Egg shape index & $81.28^{a}$ & $79.30^{\mathrm{ab}}$ & $77.86^{\mathrm{b}}$ & $76.59^{b}$ & 0.584 & 0.003 & 0.743 \\
\hline Yolk index & 40.12 & 39.39 & 39.49 & 40.78 & 0.439 & 0.612 & 0.270 \\
\hline Shell thickness, mm & 0.335 & 0.321 & 0.348 & 0.346 & 0.007 & 0.337 & 0.711 \\
\hline Yolk: albumen ratio & 0.543 & 0.561 & 0.549 & 0.572 & 0.008 & 0.294 & 0.880 \\
\hline Haugh unit score & 85.53 & 86.03 & 85.53 & 85.98 & 0.269 & 0.738 & 0.959 \\
\hline
\end{tabular}

'treatment groups: CSO - corn-based diet, CS5 - $50 \mathrm{~g}$ canola seed/kg, CS10 - $100 \mathrm{~g}$ canola seed /kg, CS15 - $150 \mathrm{~g}$ canola seed/kg; 2SEM - standard error of means; a-b- means with different superscripts are significantly different. 


\section{Serum biochemical components}

Mean values for serum biochemical components in layers fed diets with 0, 5,10 and 15\% FFCS are presented in Table 5.The results showed insignificant ( $P>0.05)$ difference in terms of serum protein fractions(total protein and albumen), renal function biomarkers (uric acid and creatinine), lipid profile (total cholesterol, LDL- cholesterol and HDL- cholesterol) values and liver enzymes activity (ALP, ALT and AST). On the other hand, serum triglycerides showed significant decrease in supplemented groups with FFCS up to 15 $\%$ in laying diets compared to the control.

The results showed insignificant differences in serum levels of protein fractions, liver enzymes activity, renal function biomarkers in response to the increasing levels of FFCS in laying quail diets. Similar results were reported in other studies conducted by (Szymeczko et al., 2011; Ahmed et al., 2015), in broilers fed rape seeds. Additionally, the insignificant effect in serum ALP activity as influenced by FFCS supplementation compared to the control may be reflex to physiological stressful condition introduced in supplemented groups. In general, the results of serum biochemical components in this study indicated that, the supplemented FFCS up to $15 \%$ in laying diets did not precipitate any significant harmful effect on the health status of the laying quails, also, this is a good indication that dietary CS was well utilized by quails.

The present study did not show significant differences among experimental groups in serum total cholesterol, LDL- cholesterol and HDL- cholesterol levels, while, there was a linear and quadratic lower level of serum triglycerides compared to the control. This finding indicating feeding diets containing canola

Table 5 - Effect of dietary supplementation of canola seeds on serum biochemical components of laying Japanese quails birds at the end of the experimental period.

\begin{tabular}{|c|c|c|c|c|c|c|c|}
\hline \multirow{2}{*}{ Indices } & \multicolumn{4}{|c|}{ Dietary treatments $^{1}$} & \multirow{2}{*}{$\mathrm{SEM}^{2}$} & \multicolumn{2}{|c|}{$p$-value } \\
\hline & CS $(0 \%)$ & CS (5\%) & CS (10\%) & CS (15\%) & & Linear & Quadratic \\
\hline \multicolumn{8}{|c|}{ Protein fractions, g/dl } \\
\hline total protein & 4.04 & 3.42 & 3.62 & 3.15 & 0.225 & 0.263 & 0.870 \\
\hline albumin & 1.59 & 1.05 & 1.39 & 1.42 & 0.094 & 0.835 & 0.139 \\
\hline \multicolumn{8}{|c|}{ Liver enzymes activity, U/L } \\
\hline AST & 36.34 & 37.19 & 28.31 & 31.16 & 3.657 & 0.503 & 0.902 \\
\hline ALT & 19.80 & 14.59 & 18.39 & 22.39 & 1.749 & 0.481 & 0.219 \\
\hline ALP & 209.5 & 191.5 & 219.0 & 228.1 & 23.86 & 0.261 & 0.788 \\
\hline \multicolumn{8}{|c|}{ Renal function biomarkers, mg/dl } \\
\hline uric acid & 5.76 & 7.31 & 6.82 & 7.05 & 0.512 & 0.500 & 0.556 \\
\hline creatinine & 0.577 & 0.498 & 0.470 & 0.670 & 0.042 & 0.505 & 0.115 \\
\hline \multicolumn{8}{|l|}{ Lipid profile, mg/dl } \\
\hline triglycerides & $2029.8^{a}$ & $1351.0^{b}$ & $1266.0^{b}$ & $1363.1^{b}$ & 112.0 & 0.022 & 0.049 \\
\hline total cholesterol & 305.0 & 288.1 & 289.3 & 287.5 & 18.71 & 0.663 & 0.589 \\
\hline HDL- cholesterol & 54.82 & 49.06 & 50.47 & 53.39 & 1.870 & 0.874 & 0.296 \\
\hline LDL- cholesterol & $151.4^{a}$ & $114.40^{b}$ & $128.5^{b}$ & $126.9^{b}$ & 12.11 & 0.924 & 0.327 \\
\hline
\end{tabular}

'treatment groups: CSO - corn-based diet, CS5 - 50 g canola seed/kg, CS10 - $100 \mathrm{~g}$ canola seed /kg, CS15 - $150 \mathrm{~g}$ canola seed/kg; AST - aspartate aminotransferase, ALT - alanine aminotransferase, ALP - alkaline phosphatase, HDL - high-density lipoprotein, LDL - low-density lipoprotein; ${ }^{2}$ SEM - standard error of means; a-b- means with different superscripts are significantly different.

oil may have a potential role in regulating blood lipid profiles; this effect might be attributed to the high content of unsaturated fat content in canola oil. As mentioned previously, canola oil is characterized by low level, $7 \%$ of saturated fatty acids, high levels of unsaturated fatty acids, including $61 \%$ oleic acid, $21 \%$ linoleic acid, and $11 \%$ alpha-linolenic acid and tocopherols $700-1,200$ ppm (Lin et al., 2013). In line with previous studies by Gillingham et al. (2012), significant reductions in triglycerides levels were observed after canola oil-based diets were consumed compared with a baseline high saturated fatty acids diet. In addition, Lin et al. (2013) reported the ability of canola oil to suppress TC and LDL-C levels compared with saturated fatty acids.

\section{Thyroid activity and antioxidant status}

Serum triiodothyronine $\left(T_{3}\right)$ concentrations of laying quails fed diets with varying FFCS levels are illustrated in (Fig. 1, A). The results revealed insignificant effect in all treatments, except in $5 \%$ FFCS group which showed a numerical elevation in serum triiodothyronine concentrations compared with other treatments. Furthermore, antioxidant status of laying quailstreated with FFCS was greatly affected. Serum glutathione peroxidase activity in the present findings (Fig. 1, D ) 
significantly increased by increasing the inclusion levels of FFCS in birds' diets, in addition, there was numerical increase in serum glutathione content (Fig. 1,C ) by increasing the inclusion levels of FFCS. While, serum malondialdehyde contents of birds in these groups as shown in (Fig. 1, B) significantly reduced compared to the control values.

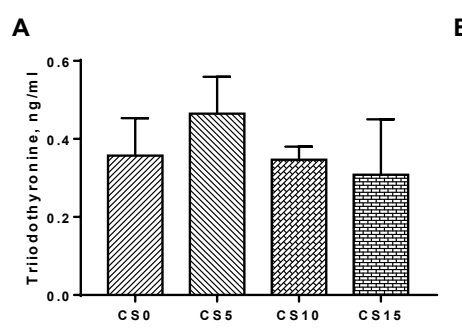

C
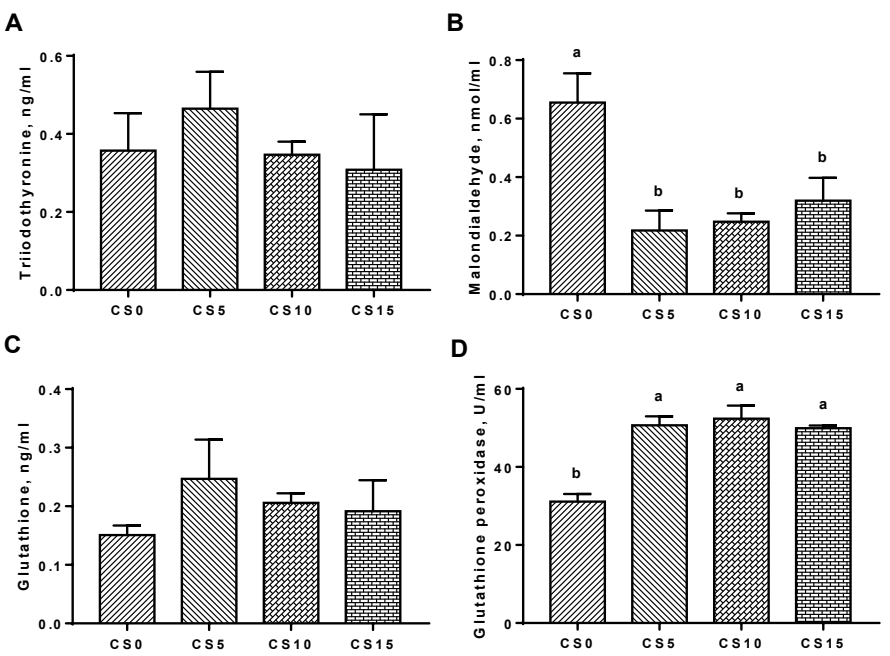

D

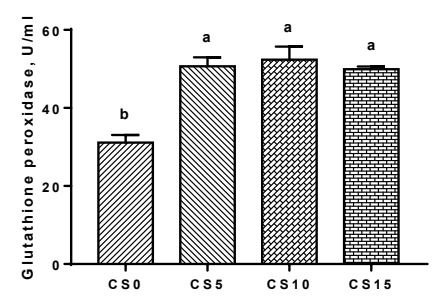

Figure 1 - Effect of dietary supplementation of canola seeds on serum concentrations of $A$ triiodothyronine, $B$ malondialdehyde, $C$ glutathione and $D$ glutathione peroxidase activity of laying Japanese quail birds at 15 weeks of age.

Treatment groups: CSO - corn-based diet, CS5 - $50 \mathrm{~g}$ canola seed $/ \mathrm{kg}$, CS10 - $100 \mathrm{~g}$ canola seed $/ \mathrm{kg}$, CS15 - $150 \mathrm{~g}$ canola seed/kg.

Data presented as mean values with their standard errors. Values with different superscript letters are statistically different $(\mathrm{P}<0.005)$.

Inclusion of FFCS at a level of 5, 10 and $15 \%$ in laying quail diets did not significantly affect serum level of $\mathrm{T}_{3}$. In agreement with our findings Ramesh et al. (2006) showed that plasma concentrations of $T_{3}$ were not affected by the addition of rapeseed meal. Taraz et al. (2006) also observed insignificant changes in serum $\mathrm{T}_{4}$ level of broilers fed rapeseed meal. In contrast, Ahmed et al. (2015) demonstrated that 10 and 20\% canola meal included in broiler diets decreased serum concentration of $T_{3}$. It was suggested that rapeseed meal contains anti-thyroid compounds that could alter the de-iodination process of the outer ring of $\mathrm{T}_{4}$ (Darras et al., 2000) and destroy nuclear receptors of thyroid hormones in the peripheral tissues (Schöne et al., 1993). However, genetically enhanced CS seems to be lower in these compounds, thus no alterations in serum T3 levels were observed in the present study. Moreover, the unchanged levels of $\mathrm{T}_{3}$ may be attributed to the physiological equilibrium in the thyroid gland of quails after 42 days of age (Ahmed et al., 2015).

The significant enhancement in serum anti-oxidative status of laying quailstreated with FFCS may be attributed to the major role of unsaturated fatty acids and phytochemical constituents present in FFCS as a natural source of antioxidants (Sameh et al., 2018), and its responsibility for health promoting action (Vallejo et al., 2003). Furthermore, the high antioxidant capacity of canola oil seeds and its high content of vitamin E (tocopherols) and phenolic compounds with levels ranging from 82 to $122 \mathrm{mg} / \mathrm{g}$ dry matter (Riaz et al., 2012; Farag et al., 2013 ; Jun et al., 2014; Chandrasekara et al., 2016; Rozan et al., 2018). In this context, Flakelar et al. (2015) and Sameh et al. (2018) showed a high total phenols, total flavonoids and $\alpha$-Tocopherol contents with superior antioxidant activity for canola meal. Lastly, this finding reflects the advantages of CS as a good source of unsaturated fatty acids, Phenolics, flavonoids and $\alpha$-tocopherols which all play an important role in the antioxidant activity.

\section{CONCLUSION}

The current study suggests that using plant breeding technologies either to produce new plant varieties or to improve the characteristics of existing varieties, including amendment of their nutritional value and reducing anti-nutritional compounds, can contribute significantly to finding potential promising alternatives to conventional feedstuffs. Replacing soybean meal and yellow maize by mutant full-fat canola seeds at levels up to $15 \%$ in laying quail diets improved laying performance indices along with the associated changes in blood biochemistry, lipids profile and antioxidative status without altering hepatic and renal function biomarkers. Thus, mutant full-fat canola seeds can be regarded as a suitable dietary alternative ingredient in laying quail diets.

\section{ACKNOWLEDGMENT}

The authors are thankful to Dr. Mona El-Sayed Farrag Mansour, Lecturer of plant research Dep., Nuclear Research Center, for providing us with mutant canola seeds. The authors also acknowledge the Biological Application Department, Nuclear Research Center, Egyptian Atomic Energy Authority for their cooperation.

\section{COMPLIANCE WITH ETHICAL STANDARDS}

The study was approved by the Ethics Committee of Local Experimental Animals Care Committee, Egyptian Nuclear Research Center. 


\section{CONFLICT OF INTEREST}

The authors declare that they have no conflict of interest.

\section{REFERENCES}

Abd El-Moneim AE, Sabic EM. Beneficial effect of feeding olive pulp and Aspergillus awamori on productive performance, egg quality, serum/ yolk cholesterol and oxidative status in laying Japanese quails. Journal of Animal and Feed Sciences 2019;28:52-61.

Abd El-Moneim AE, Sabic EM, Abu-Taleb AM. Influence of dietary supplementation of irradiated or non-irradiated olive pulp on biochemical profile, antioxidant status and immune response of Japanese quails. Biological Rhythm Research. In Press 2019.

Agah MJ, Moghaddam HN, Tahmasbi AM, Lotfollahian H. Performance and fatty acid compositions of yolk lipid from laying hens fed with locally produced canola seed (Brassica napus L.). Research Journal of Biological Sciences 2010;5:228-232.

Ahmed HA, Abou-Elkhair R, Ketkat SA, Selim S. Growth and economic performance of broiler chickens fed on graded levels of canola meal with or without multi-enzyme supplementation. Journal of Agricultural Science 2015;7(6):137.

Amer I, Farrag M, Soliman S, Hassan A. Evaluation of promising mutant lines of canola grown under new reclamation lands (Harsh Lands). Arab Journal of Nuclear Sciences and Applications 2017;(50):174-180.

Anwar MM, Ali SE, Nasr EH. Improving the nutritional value of canola seed by gamma irradiation. Journal of Radiation Research and Applied Sciences 2015;8(3):328-333.

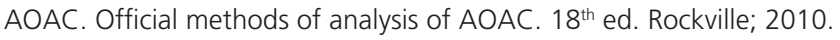

Akeson WR, Stahmann MA. A pepsin Pancreatin digest index of protein quality evaluation. Journal of Nutrition 1984;83:257.

Chandrasekara A, Rasek OA, John JA, Chandrasekara N, Shahidi F. Solvent and extraction conditions control the assayable phenolic content and antioxidant activities of seeds of black beans, canola and millet. Journal of the American Oil Chemists' Society 2016;93:275-283.

Darras VM, Van der Geyten, S, Kühn, ER. Thyroid hormone metabolism in poultry. Biotechnologie, Agronomie, Société et Environnement 2000;4:13-20.

Farrag EM. Genetic analysis of some mutant lines by gamma rays in canola (Brassica napus L.) [thesis]. Zagazig (EGY): Zagazig University; 2019.

Farag MA, Sharaf Eldin MG, Kassem H, Abou el Fetouh M. Metabolome classification of Brassica napus L. organs via UPLC-QTOF-PDA-MS and their anti-oxidant potential. Phytochemical Analysis 2013;24:277-287.

Farahat M, Hassanein E, Abdel-Razik W, Noll S. Effect of dietary corn dried distillers grains with soluble, canola meal, and chloride on electrolyte balance, growth performance, and litter moisture of growing turkeys. Poultry Science 2013;92(5):1254-1265.

Flakelar CL, Luckett DJ, Howitt JA, Doran G, Prenzler PD. "Canola (Brassica napus):oil from Australian cultivars shows promising levels of tocopherols and carotenoids, along with good oxidative stability. Journal of Food Composition and Analysis 2015;42:179-186.

Gardrat C, Prevot A. Quantitative determination of glucosinolates in rapeseed and rapeseed meal by enzymatic method. Revue Francaise des Corps Gras 1987;34:457-461.
Gillingham LG, Robinson KS, Jones PJH. Effect of high-oleic canola and flaxseed oils on energy expenditure and body composition in hypercholesterolemic subjects. Metabolism 2012;61:1598-1605.

Ibrahim NS, Sabic EM, Abu-Taleb AM. Effect of inclusion irradiated olive pulp in laying quail diets on biological Performance. Journal of Radiation Research and Applied Science 2018;11(4):340-346.

ZU, Riaz HP, et al. Effects of egg weight on the egg quality, chick quality, and broiler performance at the later stages of production (week 60):in broiler breeders. The Journal of Applied Poultry Research 2017;26(2):183-191.

Ismail IB, Al-Busadah KA, El-BahrS M. Effect of dietary supplementation of canola oil on egg production, quality and biochemistry of egg yolk and plasma of laying hen. International Journal of Biological Chemistry 2013;7:27-37

Jasinski S, Chardon F, Nesi N, Lécureuil A, Guerche P. Improving seed oil and protein content in Brassicaceae: some new genetic insights from Arabidopsis thaliana. Oilseeds \& Fats Crop and Lipids 2018;25(6):D603.

Jun HI, Wiesenborn DP,Kim YS. Antioxidant activity of phenolic compounds from canola (Brassica napus) seed. Food Science and Biotechnology 2014;23(6):1753-1760

Keum MC, An BK, Shin KH, Lee KW. Influence of dietary fat sources and conjugated fatty acid on egg quality, yolk cholesterol, and yolk fatty acid composition of laying hens. Brazilian Journal of Animal Science 2018; 47:e20170303.

Khajali F, Slominski B. Factors that affect the nutritive value of canola mea for poultry. Poultry Science 2012; 91(10):2564-2575

Kucukersan K, Yesilbag D, Kucukersan S. Influence of different dietary oil sources on performance and cholesterol content of egg yolk in laying hens. Journal of Biological and Environmental Sciences 2010;(4):117122.

Lin L, Allemekinders H, Dansby A, Campbell L, Durance-Tod S, Berger $A$, et al. Evidence of health benefits of canola oil. Nutrition Reviews 2013;71(6):370-385

Mailer RJ, McFadden A, Ayton J, Redden B. Anti-nutritional components, fibre, sinapine and glucosinolate content, in Australian canola (Brassica napus L.):meal. Journal of the American Oil Chemists' Society 2008; 85(10):937-944

Mohamed A, Ponnamperma A, Pere AJ, Hafez Y. New chromophore for phytic acid determination. Cereal Chemistry 1986;63(6):475-478.

Najib $\mathrm{H}$, Al-Khateeb SA. The effect of incorporating different levels of locally produced canola seeds (Brassica napus, L.) in the diet of laying hen. International Journal Poultry Science 2004;3(7):490-496.

NaseemM, Khan S, Yousaf M. Effect of feeding various levels of canola meal on the performance of broiler chicks. Journal of Animal Plant Science 2006:16:3-4.

Niemann G, Brand T, Hoffman L. Production and slaughter performance of ostriches fed full-fat canola seed. South African Journal of Animal Science 2018;(48):779-799.

NRC. Nutrient requirements of poultry. $9^{\text {th }}$ ed. Washington: National Academy Press; 1994.

Ramesh K, Devegowda G, Khosravinia H. Effects of enzyme addition to broiler diets containing varying levels of double zero rapeseed meal. Asian-Australasian Journal of Animal Sciences 2006;19:1354-1360.

Riaz T, Abbasi MA, Rehman A, Shahzadi U, Qureshi MZ, Ajaib M. Dicliptera bupleuroides: an imperative source for protection from oxidative stress. Journal of the Chemical Society of Pakistan 2012;34(2):326-332. 
Przybylski R, Gruczynska E, Aladedunye F. Performance of regular and modified canola and soybean oils in rotational frying. Journal of the American Oil Chemists' Society 2013;90:1271-1280.

Rozan MA, Bayomy HM, Boriy EG. Effects of turmeric addition on chemical composition, antioxidant activity and sensory evaluation of lentil soup. Alexandria Science Exchange Journal 2018;39:1-6.

Sameh G, Sharaf Eldin M, Hamid MS, Soad Z, KHair TM, Rozan MA. Canola Seed Meal as a Potential Source of Natural Antioxidant. Alexandria Science Exchange Journal 2018; 39(4):615-619.

Schöne F, Jahreis G, Richter G, Lange R. Evaluation of rapeseed meals in broiler chicks: effect of iodine supply and glucosinolate degradation by myrosinase or copper. Journal of the Science of Food and Agriculture 1993;(61):245-252.

Sharafi Y, Majidi MM, Goli SAH, Rashidi F. Oil content and fatty acids composition in brassica species. International Journal of Food Properties 2015;18(10):2145-2154

SPSS. PC + statistics. 18.0. Chicago: SPSS; 2010

Szymeczko R, Topoliński T, Burlikowska K, Piotrowska A, Bogusławska-Tryk $M$, Błaszyk J. Effects of different levels of rape seeds in the diet on performance, blood and bone parameters of broiler chickens. Journal of Central European Agriculture 2011;11:393-400.
Taraz Z, Jalali S, Rafeie F. Effects of replacement of soybean meal with rapeseed meal on organs weight, some blood biochemical parameters and performance of broiler chicks. International Journal of Poultry Science 2006;5:1110-1115.

Vallejo F, García-Viguera C, Tomás-Barberán FA. Changes in broccoli (Brassica oleracea L. var. italica) health-promoting compounds with inflorescence development. Journal of Agricultural and Food Chemistry 2003;51(13):3776-3782.

Williams KC. Some factors affecting albumen quality with particular reference to Haugh unit score. World's Poultry Science Journal 1992;48:5-16.

Zanini S, Colnago G, Pessotti B, Bastos M, Casagrande FP, Lima, V. Body fat of broiler chickens fed diets with two fat sources and conjugated linoleic acid. International Journal of Poultry Science 2006;5(3):241246. 
